\title{
Bacterial microcompartments for isethionate desulfonation in the taurine-degrading human- gut bacterium Bilophila wadsworthia
}

\author{
Anna G. Burrichter ${ }^{1,2,3^{*}}$, Stefanie Dörr ${ }^{1}$, Paavo Bergmann ${ }^{4}$, Sebastian Haiß ${ }^{1}$, Anja Keller ${ }^{1,2}$, Corentin Fournier ${ }^{1}$, \\ Paolo Franchini ${ }^{1}$, Erika Isono ${ }^{1}$ and David Schleheck ${ }^{1,2^{*}}$
}

\begin{abstract}
Background: Bilophila wadsworthia, a strictly anaerobic, sulfite-reducing bacterium and common member of the human gut microbiota, has been associated with diseases such as appendicitis and colitis. It is specialized on organosulfonate respiration for energy conservation, i.e., utilization of dietary and host-derived organosulfonates, such as taurine (2-aminoethansulfonate), as sulfite donors for sulfite respiration, producing hydrogen sulfide $\left(\mathrm{H}_{2} \mathrm{~S}\right)$, an important intestinal metabolite that may have beneficial as well as detrimental effects on the colonic environment. Its taurine desulfonation pathway involves the glycyl radical enzyme (GRE) isethionate sulfite-lyase (ISIAB), which cleaves isethionate (2-hydroxyethanesulfonate) into acetaldehyde and sulfite.

Results: We demonstrate that taurine metabolism in B. wadsworthia 3.1.6 involves bacterial microcompartments (BMCs). First, we confirmed taurine-inducible production of BMCs by proteomic, transcriptomic and ultra-thin sectioning and electron-microscopical analyses. Then, we isolated BMCs from taurine-grown cells by density-gradient ultracentrifugation and analyzed their composition by proteomics as well as by enzyme assays, which suggested that the GRE ISIAB and acetaldehyde dehydrogenase are located inside of the BMCs. Finally, we are discussing the recycling of cofactors in the IsIAB-BMCs and a potential shuttling of electrons across the BMC shell by a potential iron-sulfur (FeS) cluster-containing shell protein identified by sequence analysis.

Conclusions: We characterized a novel subclass of BMCs and broadened the spectrum of reactions known to take place enclosed in BMCs, which is of biotechnological interest. We also provided more details on the energy metabolism of the opportunistic pathobiont B. wadsworthia and on microbial $\mathrm{H}_{2} \mathrm{~S}$ production in the human gut.
\end{abstract}

\section{Introduction}

Bilophila wadsworthia is an obligately anaerobic, sulfite-reducing bacterium and part of the normal human gut flora. It has also been associated with diseases such as abscesses, appendicitis, colitis or Parkinson's disease. B. wadsworthia is able to utilize

\footnotetext{
*Correspondence: anna.burrichter@uni-konstanz.de; david.schleheck@unikonstanz.de

${ }^{2}$ Konstanz Research School Chemical Biology, University of Konstanz, Konstanz, Germany

Full list of author information is available at the end of the article
}

taurine (2-aminoethanesulfonate) as well as isethionate (2-hydroxyethanesulfonate) as sources of sulfite as terminal electron acceptor, in a process termed 'organosulfonate respiration' [1], with hydrogen sulfide $\left(\mathrm{H}_{2} \mathrm{~S}\right)$ as an end product [2]. Bacterial $\mathrm{H}_{2} \mathrm{~S}$ production has previously been implicated as an important factor in the development of inflammatory bowel diseases such as colitis [3-5] and colon cancer [6], an effect potentially due to its destructive influence on the mucus barrier of the colon $[7,8]$ and its genotoxicity $[9,10]$. On the other hand, $\mathrm{H}_{2} \mathrm{~S}$ as a "Janus-faced metabolite" [11] can also function as an intracellular antioxidant, a signaling molecule or a

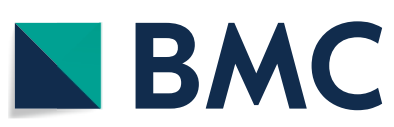

(c) The Author(s) 2021. Open Access This article is licensed under a Creative Commons Attribution 4.0 International License, which permits use, sharing, adaptation, distribution and reproduction in any medium or format, as long as you give appropriate credit to the original author(s) and the source, provide a link to the Creative Commons licence, and indicate if changes were made. The images or other third party material in this article are included in the article's Creative Commons licence, unless indicated otherwise in a credit line to the material. If material is not included in the article's Creative Commons licence and your intended use is not permitted by statutory regulation or exceeds the permitted use, you will need to obtain permission directly from the copyright holder. To view a copy of this licence, visit http://creativecommons.org/licenses/by/4.0/. The Creative Commons Public Domain Dedication waiver (http://creativeco mmons.org/publicdomain/zero/1.0/) applies to the data made available in this article, unless otherwise stated in a credit line to the data. 
mitochondrial energy source [12] and therefore may have beneficial impacts on the host in a dose-dependent manner [13].

Taurine as substrate for $B$. wadsworthia can enter the human digestive system as part of the diet, e.g. as a constituent of meat [14, 15] and energy drinks [16], while isethionate can be found in seafood [17, 18]. More importantly, taurine is produced by the human body, for example as a conjugate for bile salts such as taurocholate [19-21]. It was shown that both a diet rich in saturated fats stimulating bile salt production, including taurocholate, and a diet supplemented directly with taurocholate, can lead to B. wadsworthia blooms and subsequent development of colitis in mice [22]. The taurine catabolism of $B$. wadsworthia thus provides an intriguing link between dietary conditions, microbial $\mathrm{H}_{2} \mathrm{~S}$ production and disease development in animals and humans [21].

While $B$. wadsworthia produces $\mathrm{H}_{2} \mathrm{~S}$ from the sulfite released from organosulfonates using the dissimilatory sulfite reductase complex (Dsr), it is unable to use inorganic sulfate as electron acceptor [2] since its genome lacks the genes for sulfate adenylyltransferase (Sat) and adenosine 5'-phosphosulfate reductase (AprAB). B. wadsworthia is thus unable to activate sulfate and reductively cleave adenosine 5 '-phosphosulfate to sulfite and adenosine monophosphate.

Only recently, the complete desulfonation pathway for taurine in B. wadsworthia was elucidated and shown to include a new class of glycyl radical enzymes (GREs) that cleaves the carbon-sulfur bond in isethionate $[1,23]$. The complete pathway is illustrated in Fig. 1 A. Taurine is first deaminated to sulfoacetaldehyde by a taurinepyruvate aminotransferase (Tpa), which is then reduced to isethionate by a NADH-dependent sulfoacetaldehyde reductase $(\mathrm{SarD})$. Isethionate is the substrate for the GRE isethionate-sulfite lyase (IslA), which is activated by its activating enzyme IslB using $S$-adenoslymethionine (SAM) as the initial radical donor. This radical-mediated cleavage reaction, which is extremely oxygen sensitive [1], results in the sulfonate group of isethionate being released as sulfite and of the carbon moiety as acetaldehyde. Both sulfite and acetaldehyde can be harmful to cellular processes, as both can damage proteins, DNA and lipids through formation of adducts and are therefore quickly detoxified by most organisms [24, 25].

Sulfite released from isethionate is utilized as terminal electron acceptor by the Dsr complex, producing $\mathrm{H}_{2} \mathrm{~S}$ (Fig. 1 A). Notably, this choice of electron acceptor is energetically beneficial compared to sulfate reduction, in that no investment of two ATP equivalents for the activation of sulfate is necessary [1]. Acetaldehyde is oxidized to acetate via acetyl-CoA and acetylphosphate, yielding one ATP in the process. As this pathway is not balanced in respect to electrons, an additional electron donor such as lactate, formate or molecular hydrogen $\left(\mathrm{H}_{2}\right)$ [34] is necessary to provide electrons to the Dsr complex for respiration and energy conservation. Indeed, $B$. wadsworthia is able to utilize organosulfonates as terminal electron acceptors but not as sole substrates for fermentation [2, 34].

The genes for the taurine desulfonation pathway are encoded in two clusters that are regulated independently (Fig. 1): One taurine-inducible cluster (not shown in Fig. 1B) encoding for the enzymes for conversion of taurine to isethionate (i.e., genes for Tpa, for pyruvateregenerating alanine dehydrogenase, and for $\operatorname{SarD}$ ), and a second, taurine- and isethionate-inducible gene cluster (as shown in Fig. 1B) comprising the genes for IslA, IslB and AdhE.

Intriguingly, this second, IslAB-AdhE gene cluster contains also several genes that are predicted to encode for shell proteins of bacterial microcompartments (BMCs) (see Fig. 1B), suggesting that BMCs might play a role in the taurine desulfonation pathway in B. wadsworthia 3.1.6 (see below). BMCs are small (40-600 nm in diameter [35-37]) organelle-like compartments constructed entirely from protein that exist within the bacterial cytosol. They isolate reactions that produce highly reactive and/or volatile intermediates, usually aldehydes, e.g. during the catabolism of ethanolamine or propanediol $[28,42-44]$, and/or improve the efficiency of enzymes such as $\mathrm{CO}_{2}$-fixing ribulose-1,5-bisphosphate carboxylase/oxygenase [38-41] or multistep pathways [35]. It has been shown that genes encoding BMC shells can be transferred between bacterial species [33, 47, 48] and even between bacteria and plants $[49,50]$, making them an interesting module for biotechnological engineering. Indeed, BMCs employed as 'intracellular bioreactors' can increase bacterial production of ethanol [51] or improve phosphate removal from the medium by increasing the production of polyphosphates [52].

Glycyl radical enzymes (GREs) are the so- called signature enzymes of a range of BMCs. Two welldefined examples are choline trimethylamine-lyase (CutC) in, for example, Desulfovibrio desulfuricans and Escherichia coli $[53,54]$ and $\mathrm{B}_{12}$-independent glycerol dehydratase in Clostridium butyricum and Rhodobacter capsulatus [55-58]. Other classes of potentially GRE-containing BMCs were defined by genomic analyses $[59,60]$, but as of yet their function has only been studied in one case, for propanediol utilization [58].

In $B$. wadsworthia, the putative genes for BMC shell proteins are co-located in a predicted operon with the genes for IslAB and AdhE (see Fig. 1B). Hence, we speculated that the radical cleavage of isethionate by the extremely oxygen-sensitive IslAB, yielding two toxic 


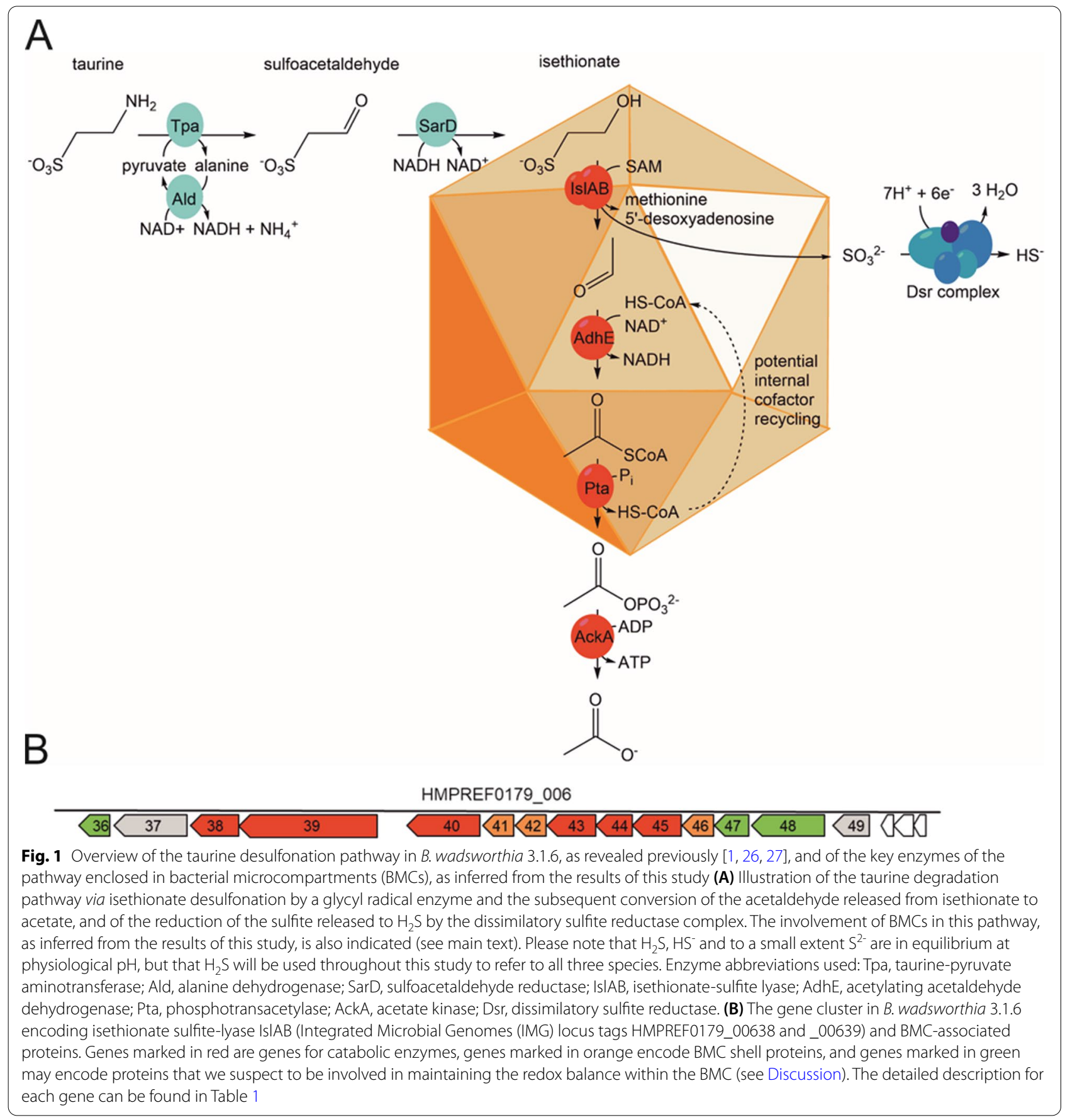

products, sulfite and acetaldehyde, may be isolated within a BMC in B. wadsworthia.

In this study, we demonstrated the production of BMCs in B. wadsworthia 3.1.6 and examined their association with the enzymes of the taurine desulfonation pathway. The expression of BMCs in taurine-grown
B. wadsworthia cells was shown using electron microscope, transcriptomic and proteomic analyses. Further, the BMCs were separated from cell-free extracts using sucrose-gradient centrifugation and examined by electron-microscopy and proteomic analysis as well as by specific enzyme assays. 
Table 1 Annotations and predicted functions of genes in the IsIAB gene cluster. All initial annotations were taken from the original IMG annotation for Bilophila wadsworthia 3.1.6. The prefix to yield a complete IMG locus tag is HMPREF0179_

\begin{tabular}{|c|c|c|}
\hline Locus tag & Annotation & Predicted gene product function \\
\hline 00636 & TIGR04076 family protein & potentially involved in redox reactions or iron cluster metabolism \\
\hline 00637 & PAS domain S-box-containing protein & transcriptional regulator \\
\hline 00638 & pyruvate formate lyase activating enzyme & Is|A-activating enzyme, Is|B (confirmed, see [1]) \\
\hline 00639 & formate C-acetyltransferase & isethionate sulfite-lyase, IsIA (confirmed, see [1]) \\
\hline 00640 & aldehyde dehydrogenase & acetylating acetaldehyde dehydrogenase (confirmed, see [1]) \\
\hline 00641 & ethanolamine utilization protein EutN & BMC shell protein $[28,29]$ \\
\hline 00642 & ethanolamine utilization protein EutN & BMC shell protein $[28,29]$ \\
\hline 00643 & phosphotransacetylase & phosphotransacetylase \\
\hline 00644 & ethanolamine utilization cobalamin adenosyltransferase & unclear (see Discussion) \\
\hline 00645 & ethanolamine utilization protein EutQ & putative acetate kinase [30] \\
\hline 00646 & BMC domain-containing shell protein & \\
\hline 00647 & $\begin{array}{l}\text { Carboxysome shell and ethanolamine utilization microcompart- } \\
\text { ment protein } \mathrm{CcmL} / \text { EutN }\end{array}$ & $\begin{array}{l}\text { protein alignment (BLAST) revealed it to be also similar to PduT, a } \\
\text { shell protein from propanediol utilization microcompartments that } \\
\text { contain } 4 \text { Fe-4 S cluster [31-33] (see also Discussion) }\end{array}$ \\
\hline 00648 & $\begin{array}{l}\mathrm{Na}^{+} \text {-translocating ferredoxin:NAD }{ }^{+} \text {oxidoreductase RNF (RnfC } \\
\text { subunit) }\end{array}$ & $\begin{array}{l}\text { based on its four protein family (pfam) domains, we conclude it to be } \\
\text { a PduS homolog (see Discussion) }\end{array}$ \\
\hline 00649 & hypothetical protein & predicted amidohydrolase function (IMG) \\
\hline
\end{tabular}

\section{Results}

Transcriptomic and proteomic analyses confirm expression of BMC shell proteins during growth with taurine

The gene cluster (predicted operon) in B. wadsworthia 3.1.6 encoding for IslAB and AdhE contains also four predicted genes for BMC shell proteins (Introduction, Fig. 1B), and we therefore examined by transcriptomics and proteomics whether these BMC genes/proteins may be co-induced during degradation of taurine. Taurine-grown cultures of $B$. wadsworthia $(\mathrm{n}=3)$ were analyzed either by proteomics against 3-sulfolactategrown cultures $(n=3)$, or by transcriptional analysis $(n$ $=3$ ) against a 2,3-dihydroxy-propanesulfonate-grown culture $(n=1)$ as the reference (see also Discussion). Figure 2 A shows a direct comparison of the proteomic and transcriptomic data for relevant proteins/ genes as detected each in taurine-grown cells, and Fig. 2B shows a comparison of the proteomic data for taurine-grown cells in comparison to 3-sulfolactategrown cells. The transcriptomic data for the 2,3-dihydroxypropane-sulfonate-grown culture is shown in the Supplementary file, Figure S1. Overall, the data confirmed a strong inducible expression of IslAB and AdhE during growth with taurine [1]. The data showed also that the shell protein genes HMPREF0179_00641 and HMPREF0179_ 00642 (both annotated as EutN), HMPREF0179_00646 (CcmK-like shell protein) and HMPREF0179_00647 (CcmL/PduT), are more strongly induced during growth with taurine as electron acceptor both at the transcriptional (Fig. 2 A; Figure S1) and at the protein level (Fig. 2B). Hence, B. wadsworthia 3.1.6 indeed produced BMC shell proteins during taurine degradation and, thus, most likely BMCs. In the next step, we aimed at a visual confirmation of such sub-cellular compartments in B. wadsworthia 3.1 .6 cells by electron microscopy.

\section{Confirmation of BMC production by transmission electron microscopy}

Ultrathin sections of epoxy-embedded $B$. wadsworthia cells grown with taurine as the electron acceptor were examined for the existence of BMCs by transmission electron microscopy (TEM) (Fig. 3AB). Multiple polyhedral structures of $50-100 \mathrm{~nm}$ in diameter were visible, essentially, in all cells examined (see Fig. 3A). These structures closely resembled the structures in Desulfovibrio alaskensis cells grown with choline (Figure S2), conditions that are known to lead to BMC formation in this organism [61]. These structures were not present in B. wadsworthia cells grown with 3-sulfolactate (Fig. 3B). 3-sulfolactate is desulfonated by a different inducible enzyme, 3-sulfolactate sulfite-lyase (SuyAB) [62, 63] (see Fig. 2B). SuyAB is not oxygen sensitive and produces sulfite and non-toxic pyruvate, in comparison to the acetaldehyde produced by IslAB (see Discussion), and is therefore not expected to lead to the formation of BMCs. Further, the gene cluster for SuyAB does not contain BMC shell protein genes (Figure S3). Correspondingly, the shell proteins 


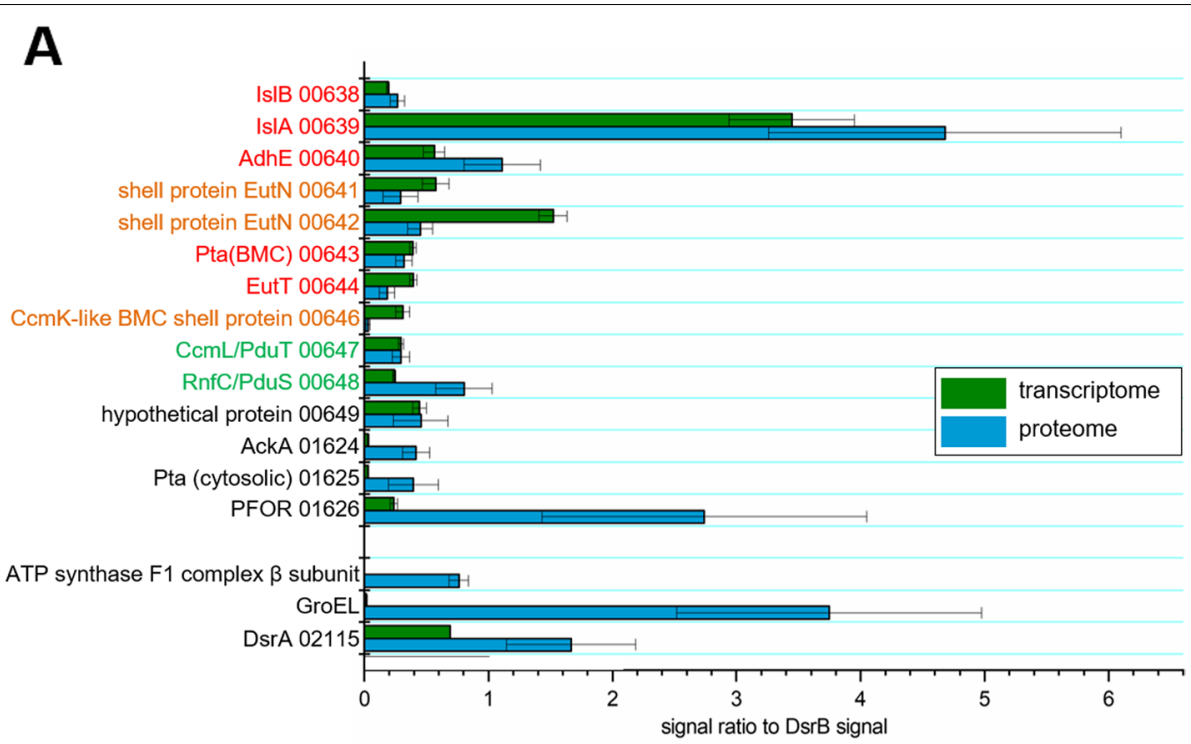

B

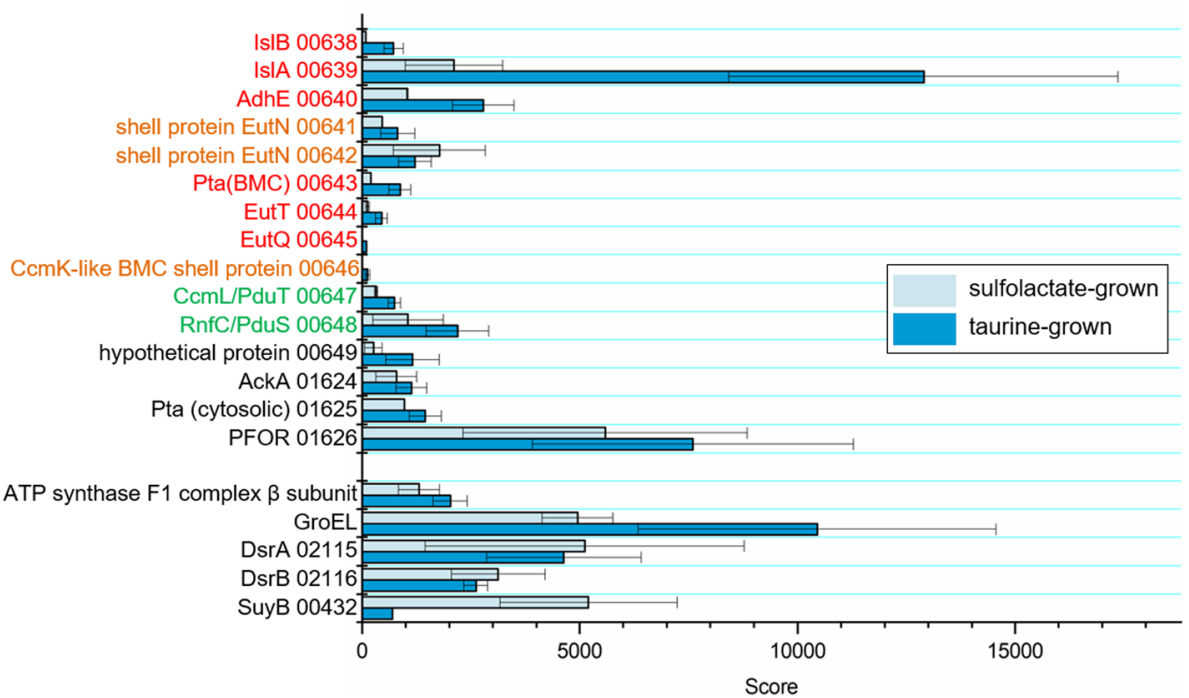

Fig. 2 Excerpts of the total transcriptomic and proteomic data for B. wadsworthia in respect to the expression of BMC shell proteins during taurine degradation (A): Proteomic (blue) and transcriptomic (green) identification of produced or induced proteins/genes in B. wadsworthia during growth with taurine as electron acceptor. Values are normalized to the DsrB signal to enable comparison between the two methods. Note that the transcription of the genes for the small BMC shell proteins such as (IMG locus tag prefix HMPREF0179_) genes 00641,00642 (both annotated as EutN) and 00646 (CcmK-like shell protein) appeared to be higher relative to the proteomic scores in comparison to the data for larger genes/proteins (e.g. for IsIA, GroEL, PFOR), and that this observation may be attributed to the proteomic analysis, where smaller proteins are detected with lower sensitivity than larger proteins. Error bars: standard deviation of $n=3$ (B) Excerpt of total proteomic data for B. wadsworthia grown with taurine (dark blue) in comparison to 3-sulfolactate (light blue) as electron acceptor. For taurine respiration, a higher expression of ISIAB was confirmed, as well as of other BMC-associated proteins from the gene cluster represented in Fig. 1B, such as the shell proteins EutN (00641), a CcmK-like shell protein (00646) and CcmL/PduT (00647). Sulfolactate respiration on the other hand led to much higher expression of the corresponding desulfonating enzyme, SuyAB (see text), in comparison to taurine respiration. Data for constitutively expressed proteins is also shown for comparison (e.g. GroEL, ATP synthase subunits). Data represents the mean \pm standard error from the analysis of three biological replicates (cultures) for taurine- and of two biological replicates for sulfolactate-grown B. wadsworthia 3.1.6

encoded in the IslAB gene cluster were detected only at low abundance in cells grown with 3 -sulfolactate (Fig. 2B).

\section{Separation of BMCs by sucrose gradient centrifugation} We aimed at purifying the BMCs using a sucrose gradient centrifugation, which separates cell components according to their sedimentation speed (see Methods). 

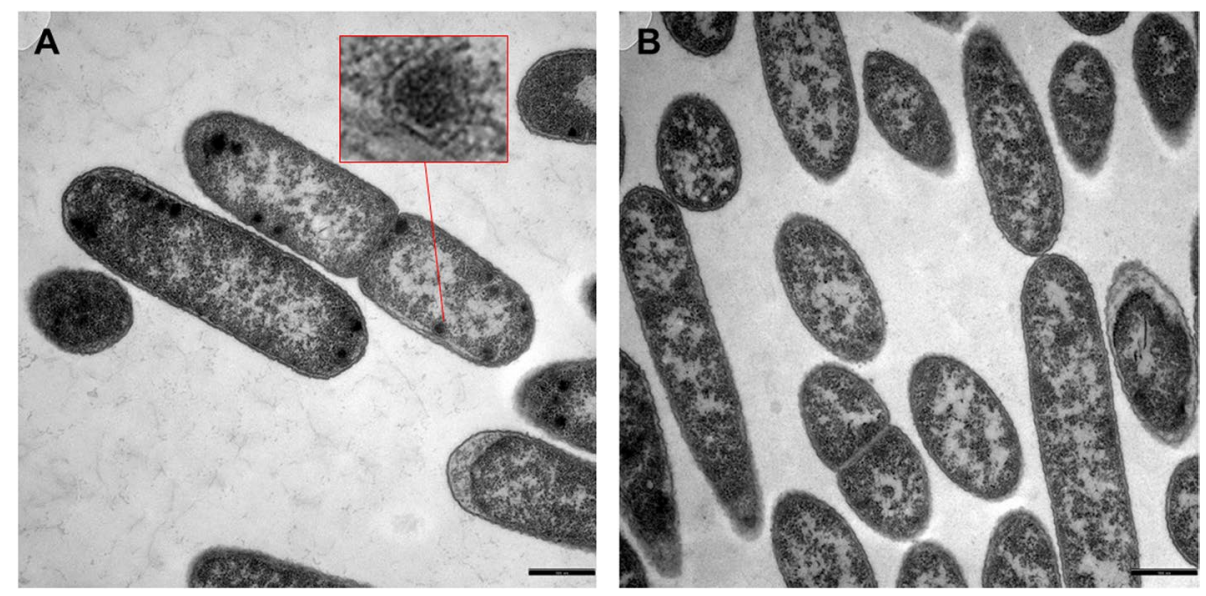

Fig. 3 TEM images of ultrathin sections of $B$. wadsworthia cells grown with taurine (A) or 3-sulfolactate as the electron acceptor (B). Polyhedral structures characteristic of BMCs were observed specifically for taurine-grown cells. Scale bars: $500 \mathrm{~nm}$. The inset in (A) is a 6x magnification. The structures in B. wadsworthia appeared very similar to these in the BMC-producing Desulfovibrio alaskensis during growth with choline (see Figure S2), as previously described [64]

As shown in Fig. 4, a total of ten clearly distinguishable bands were visible after centrifugation and were collected separately into ten fractions. SDS-PAGE analysis was employed for preliminary attribution of these fractions (Fig. 4C): The distinctive band of the glycyl radical enzyme IslA (93.9 kDa molecular weight, confirmed by proteomic analysis and marked with the red box in Fig. 4C) was found in fractions 3 to 5 , and was most prominent in fraction 4 , suggesting that this was the main fraction in which also BMCs were contained. Indeed, when fraction 4 was analyzed by TEM, it was found to contain microcompartment-like structures (Fig. 4B), suggesting that also intact BMCs were purified in fraction 4. Fraction 2 contained a diverse mixture of proteins, but no distinct band at $94 \mathrm{kDa}$, and we presumed this to be the fraction of predominantly soluble cytosolic proteins.

SDS-PAGE bands from fractions 3 and 4 in the size range of predicted $\mathrm{BMC}$ shell proteins were identified by proteomics (Table S2) as EutN (HMPREF0179_00642 and HMPREF0179_00647), a known shell protein from ethanolamine utilization BMCs, among many other proteins, especially ribosomal proteins (see Table S2). We concluded that the fractions containing IslA also contained identified BMC shell proteins, and that ribosomes, in size and composition comparable to small BMCs, may have been co-purified with the BMCs using the centrifugation protocol.

\section{Proteomic analysis of the sucrose gradient fractions}

The BMC-containing fraction 4 was analyzed also by semi-quantitative total proteomics (i.e., without
SDS-PAGE separation) relative to fractions 2,3 and 5 . Figure 5 shows the relative abundance of selected proteins within each dataset and throughout the gradient fractions (yellow, fraction 2; orange, fraction 3; red, fraction 4 [BMC fraction]; pink, fraction 5). The cytosolic chaperone DnaK served as a control. It was detected in higher relative abundance (i.e., with higher score) in fractions 2 and 3 than in fractions 4 and 5, as expected for a cytosolic protein. For the components of the BMC signature enzyme IslAB a contrasting distribution was found. They were more prominently detected in fractions 4 and 5 , further confirming that these were the fractions containing BMCs. Interestingly, a similar abundance pattern was observed for the DsrAB components of sulfite reductase, for pyruvate:ferredoxin oxidoreductase (PFOR) and to a certain extent also for aldehyde dehydrogenase (AdhE), phosphotransacetylase (Pta), the RnfC subunit oxidoreductase and alanine dehydrogenase (Ald). Shell proteins, acetate kinase (AckA), and the enzymes converting taurine to isethionate ( $\mathrm{Tpa}, \mathrm{SarD})$, appeared to be more abundant in the cytosolic fraction 2 and in the intermediate fraction 3 . The shell proteins detected in the soluble protein fractions resulted most likely from fractured BMCs or monomeric shell proteins (10-20 kDa).

\section{Specific enzyme activities detected in sucrose gradient fractions}

We also measured specific activities of the taurine pathway enzymes associated to the different gradient fractions (Fig. 6), aiming to relate these activities to the protein abundances as observed by proteomics. 

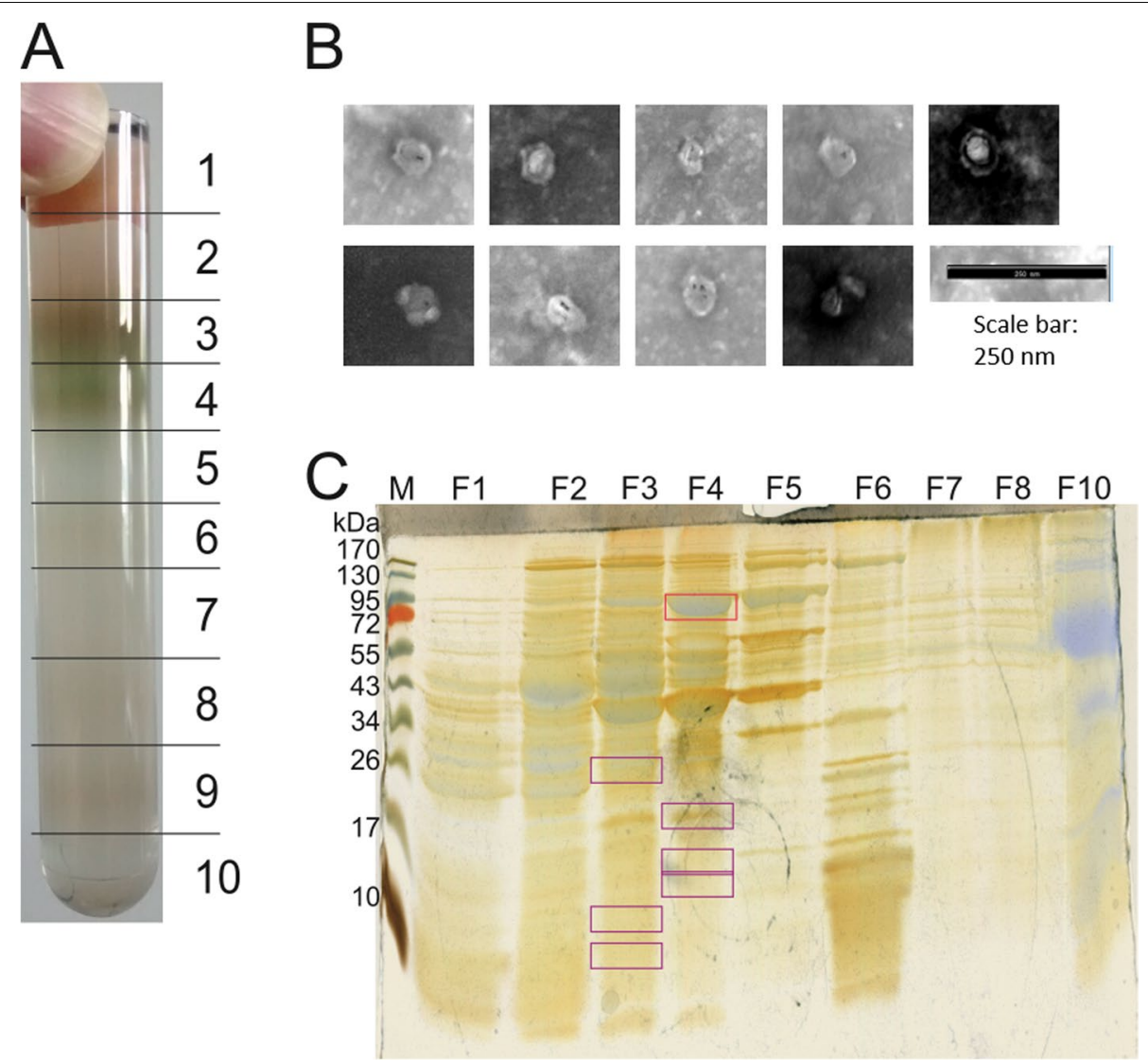

Fig. 4 Sucrose gradient purification of BMCs from cell-free extracts of B. wadsworthia. (A) Photograph of a sucrose gradient after centrifugation. The numbers mark the fractions that were collected. Fraction 2 contained most of the soluble cytosolic proteins, fraction 3 broken BMCs, while fraction 4 contained intact BMCs (see $\mathbf{C}$ ). Fraction 10 contained also the centrifugation pellet; it was resuspended in fraction-10 solution $(0.5 \mathrm{ml})$ and included in the SDS-PAGE analysis. (B) Nine excerpts of negative-stained TEM images of fraction 4, each showing sections where microcompartment-like structures were observed. (C) Double-stained (Coomassie and silver) SDS-PAGE gel of the gradient fractions (lanes from left to right: size marker (M), fractions 1 through 8, fraction 10). The upper red box marks the molecular weight of the signature enzyme of the BMC, isethionate sulfite-lyase (IsIA) at approximately $94 \mathrm{kDa}$. The strong band at $40 \mathrm{kDa}$ correspond to SarD ( $40.8 \mathrm{kDa})$ and Ald (39.8 kDa). The purple boxes mark bands that were identified by proteomic analysis as BMC shell proteins for fractions 4 and fraction 3 (see main text), which were visible only through silver staining. Fraction 9 was not included in the analysis as it contained only an insignificant amount of protein. M, protein molecular mass markers

Isethionate-cleaving activity of IslAB was measurable in the BMC fraction 4 and to a lower extent in the neighboring fractions 3 and 5, confirming the distribution displayed by the proteomic data (Fig. 6B). Both the formation of acetaldehyde and sulfite was detectable in the BMC fractions after incubation with isethionate and $S$-adenosylmethionine in assays under strictly oxygenfree, reducing conditions (see Methods). For comparison, there was no acetaldehyde or sulfite formation measurable in the soluble protein fraction 2 .

The detected acetylating aldehyde dehydrogenase activity was evenly distributed across fractions 3 to 5 , again confirming the distribution pattern found in the proteomic data (Fig. 6C). Almost all of the aldehyde-oxidizing activity was found to be coenzyme A-dependent, while non-acetylating acetaldehyde oxidation was negligible.

Phosphotransacetylase activity was detected at the highest level in the intermediate fraction 3 and slightly lower in fractions 2 and 4 (Fig. 6D). As discussed below, B. wadsworthia encodes two phosphotransacetylases in its genome, which cannot be distinguished by the activity measurement; they both might have been present in different distribution along the gradients.

The highest acetate kinase activity was detected in the soluble fractions 2 and 3, confirming its distribution as suggested by the proteomic data (Fig. 6E). The activity was markedly lower in the BMC-containing fractions 4 and 5 . That this activity pattern of acetate kinase was different to that of phosphotransacetylase, which seemed 


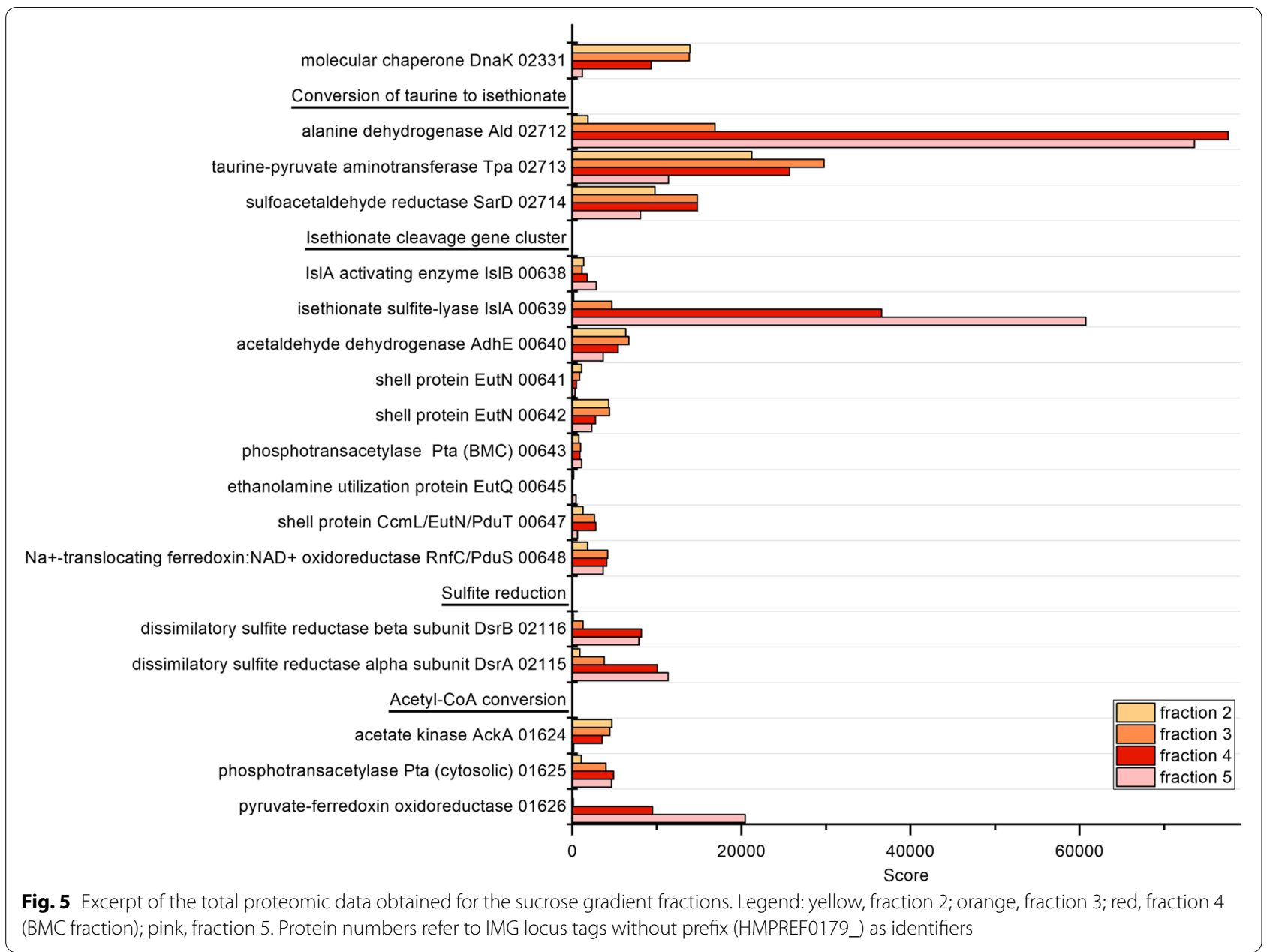

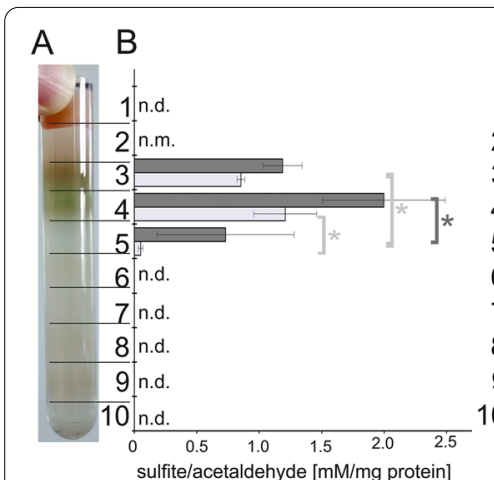

\section{C}

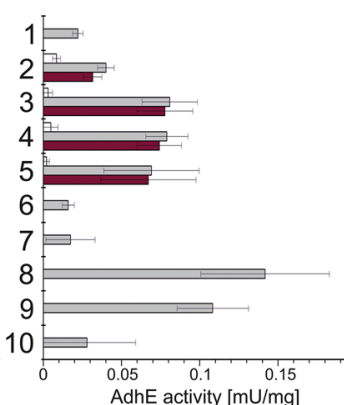

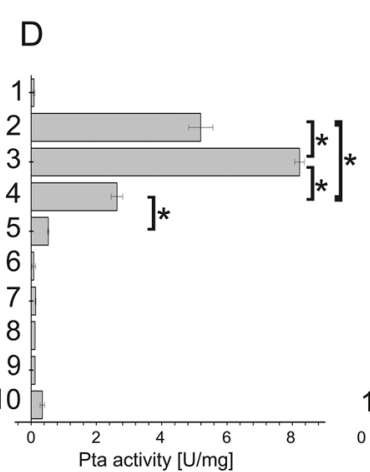

$\mathrm{E}$

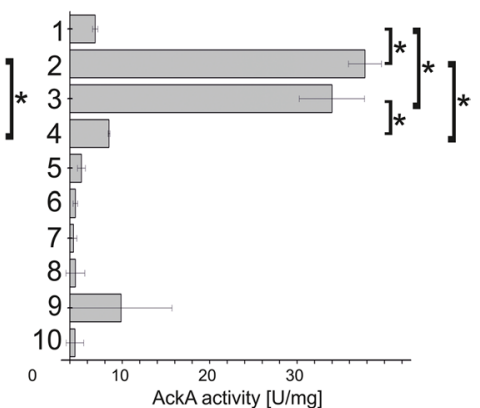

Fig. 6 Specific enzyme activities detected in the different sucrose gradient fractions (B-E) in comparison to an image of a representative gradient (A). Protein concentrations in the fractions 7-9 were typically very low and, thus, apparently high specific enzyme activities detected were considered unreliable. Specific protein activities are given as Units per mg of total protein. The figure shows means \pm standard deviation of three technical replicates, representing one of two biological replicates. Asterisks denote statistical significance at a power of 0.05 (B) IsIAB activity represented as sulfite (light gray bars) and acetaldehyde (dark gray bars) production in anoxic incubations with isethionate and S-adenosylmethionine. n.d.: not determined; n.m.: not measurable. C Specific acetaldehyde dehydrogenase activity determined photometrically as rate of $\mathrm{NADH}$ formation from $\mathrm{NAD}^{+}$. Grey bars, total acetaldehyde dehydrogenase activity (measured in presence of free coenzyme A); red bars, acetylating acetaldehyde dehydrogenase activity, calculated by subtracting non-acetylating acetaldehyde dehydrogenase activity (measured in absence of free coenzyme A). D Specific phosphotransacetylase activity measured as acetyl-CoA formation from acetyl phosphate in the presence of free coenzyme A. E Specific acetate kinase activity measured as acetyl phosphate consumption in the presence of ADP 
to be more closely associated to the BMCs, is consistent with the distinct distribution pattern as displayed by the proteomics data.

The activity of taurine-pyruvate aminotransferase (Tpa) was not measurable as the enzyme did not remain active throughout the centrifugation. Further, it was impossible to determine sulfoacetaldehyde reductase (SarD) activity in a photometrical assay against a background NADHoxidizing activity, but previous work with recombinant SarD (published in [1]) suggests that it would retain its full activity throughout the centrifugation process.

\section{Discussion}

In this study, the existence of BMCs in B. wadsworthia during growth with taurine and isethionate as electron acceptors was demonstrated by total-proteomic and transcriptomic analyses as well as by electron microscopy. Further, we succeeded in enriching the BMCs by gradient centrifugation, as confirmed by electron microscopy and proteomic analysis, and we were able to confirm IslAB enzyme activity associated to the BMC-containing fraction. Based on the clear distribution patterns of IslAB found in both the omics data and enzyme activity measurements, we conclude that IslAB is indeed the signature enzyme of these BMCs. $B$. wadsworthia likely employs these BMCs in order to isolate the desulfonating glycyl radical enzyme IslAB, which cleaves isethionate to harmful acetaldehyde and sulfite, from the cytosol. Furthermore, enzymes that process these toxic reaction products of IslAB were found to be associated to the BMCs, though it remains unclear from the data whether they are contained within, or are merely associated to the outside of the BMC. These include the aldehyde-detoxifying dehydrogenase AdhE (discussed further below) and the sulfite-reducing and, thus, sulfite-detoxifying Dsr complex, of which the DsrA and B components also seemed to be associated to the BMC-containing fraction (Fig. 5). Whether the Dsr complex is associated to, most likely, the outside of the BMCs for an efficient detoxification of sulfite remains to be addressed in future research. TEM images of ultra-thin sections of taurine-grown $B$. wadsworthia (Fig. 2A) suggest for many cells a 'crowding' of cellular structure particularly around the BMCs and, hence, it is tempting to speculate that the BMCs may indeed be covered by densely packed peripheral enzymes.

Recently, another desulfonating GRE was demonstrated in B. wadsworthia, 2,3-dihydroxypropanesulfonate (DHPS) sulfite-lyase (HpsGH), for growth with DHPS as sulfite-donor for respiration [11, 65] (see Fig. S1). This GRE is not encoded in a gene cluster associated with BMC shell protein genes and, thus, most likely is a free, cytosolic GRE in B. wadsworthia. Hydroxyacetone, the reaction product from desulfonation of DHPS might be less toxic compared to the acetaldehyde formed during the IslAB reaction. However, Desulfovibrio desulfuricans DSM642 and Desulfovibrio alaskensis G20 also employ IslAB-type GREs for isethionate desulfonation [1], and these enzyme systems are expressed from gene clusters that also do not co-encode BMC shell proteins. Hence, there seems to be no absolute necessity to encapsulate the IslAB reaction in $\mathrm{BMCs}$ for protection against toxicity of sulfite and acetaldehyde. Desulfovibrio, as 'classical' sulfate reducing bacteria being able to utilize sulfate, may utilize organosulfonates as alternative sulfite donor for respiration, while $B$. wadsworthia has specialized solely on organosulfonate respiration. The encapsulation of the IslAB-GRE reaction in BMCs might in $B$. wadsworthia thus reflect a structural specialization for competitive advantage.

The activity of acetylating acetaldehyde dehydrogenase could clearly be associated to the BMCs of $B$. wadsworthia. As known from other types of BMC [35] that harbor aldehyde dehydrogenases, acetylating acetaldehyde dehydrogenase contained within the BMC would be keeping concentrations of free acetaldehyde low. The acetyl-CoA resulting from the oxidation of acetaldehyde would be trans-esterified to acetylphosphate by Pta, a protein that, based on our proteomic data and activity measurements, seemed to be associated with the BMC, and then converted to acetate and ATP by cytosolic acetate kinase. As our enzyme assay data shows high Pta activity also in the BMC fraction, transformation of acetaldehyde via acetylCoA to acetylphosphate in the BMC is probable. The acetylphosphate would likely be shuttled out of the BMC and dephosphorylated to acetate by AckA (coupled to ATP formation), which is, based on the enzymes assays, most probably a cytosolic enzyme.

In this case, for acetylating acetaldehyde dehydrogenase and Pta being located within the BMC, coenzyme A would be regenerated within the BMC. As coenzyme A is a large cofactor compared to, for example, acetylphosphate, regeneration within the BMC would save substantial transport across the shell. Such internal cofactor recycling has been shown for ethanolamine- [66] and 1,2-propanediol-utilization [67] microcompartments. For ethanolamine utilization of Salmonella enterica, the gene for the phosphotransacetylase EutD in the BMC gene cluster has been shown by Huseby and Roth [66] to be essential even though it is functionally redundant since a second, housekeeping phosphotransacetylase gene exists elsewhere in the genome. The authors assumed that the BMC-contained Pta is essential due to its ability to recycle free coenzyme A within the BMC. A similar situation may be the case in $B$. wadsworthia, which was found to express two phosphotransacetylases as well: One whose respective gene is located within the $\mathrm{BMC}$ gene cluster 
(HMPREF0179_00643) and one that is encoded next to cytosolic acetate kinase (HMPREF0179_01625). Both of these phosphotransacetylases were found associated with the $\mathrm{BMC}$ by proteomic analysis; however, the assay we used cannot distinguish between the activities of these two enzyme homologs. It is possible that one is indeed located within the BMC and one in the cytosol. The BMC gene cluster even contains a gene annotated as EutQ which has been described as having an acetate kinase activity [30] and could catalyze the last reaction step from acetyl phosphate to acetate, but it was only detectable in low amounts in proteomic analysis; in addition, the acetate kinase activity was mainly detected in the soluble protein fraction.

The potential internal recycling of $\mathrm{NAD}^{+}$from NADH formed by acetaldehyde oxidation to acetylCoA is much more unclear, though an intriguing candidate may be a protein annotated as $\mathrm{Na}^{+}$-translocating ferredoxin: $\mathrm{NAD}^{+}$oxidoreductase (RnfC, 00648). In our proteomic analysis, this protein was found associated with the BMCs, for which it could serve as part of a redox shuttle in order to remove excess electrons from the BMC across the shell, thereby internally regenerating $\mathrm{NAD}^{+}$from $\mathrm{NADH}$. Based on the protein-family (pfam) domains, of which the motif of the RnfC subunit (pfam13375) is only one of four [68], it is more similar to the cobalamin reductase PduS from Salmonella enterica or Citrobacter freundii than to the actual Rnf complex subunit. PduS in propanediol utilization microcompartments reduces the cobalamin cofactor of $B_{12}$ from $\mathrm{Co}^{3+}$ to $\mathrm{Co}^{2+}[69,70]$ and also associates with PduT, a shell protein containing a $4 \mathrm{Fe}-4 \mathrm{~S}$ cluster [70]. A PduT homolog may be encoded in the $B$. wadsworthia gene cluster annotated as CcmL/EutN (00647): Basic Local Alignment Search (BLAST) search revealed the most closely related protein ( $69.7 \%$ identity) to be a protein of the PduT family in Telmatospirillum siberiense. Its identity to the experimentally verified PduT sequences of $C$. freundii and Salmonella typhimurium strain LT2 is 43.9 and $41.2 \%$ respectively. In the GRE-containing BMCs of B. wadsworthia, which do not involve $\mathrm{B}_{12}$ as a cofactor, the function of PduS and PduT is yet unclear. However, it is tempting to speculate that they may also serve to shuttle electrons between the outside and the inside of the BMC using the FeS cluster of PduT, as it was suggested for propanediol $[68,70]$ and ethanolamine [71] utilization microcompartments. Since the $B$. wadsworthia gene cluster contains no gene for an alcohol dehydrogenase in order to recycle $\mathrm{NAD}^{+}$within the BMCs $[66,67]$, it remains unclear how the electrons released by the acetaldehyde dehydrogenase are being shuttled further. Hence, a potential transfer of these electrons to the cytosol via the iron-sulfur clusters of PduS in the BMC lumen and PduT in the BMC shell is a viable hypothesis. It has also recently been shown that in Listeria monocytogenes, ethanolamine is anaerobically catabolized in BMCs but at the same time dependent on extracellular electron transport [71], necessitating a transfer of electrons out of the BMC. In this study, the authors also suspect this transport to take place via a PduT-like shell protein.

Both PduS and PduT are known to use flavins as well as iron-sulfur clusters as electron carriers. The electron potential of the reduced flavin cofactor of oxically purified recombinant PduS is at $-262 \mathrm{mV}$, in anoxically produced PduS, binding both the flavin cofactor and an [4Fe-4 S] center it is at $-150 \mathrm{mV}$ [70]. This means that the electrons could well be used for sulfite reduction $(-116$ $\mathrm{mV})$. However, the potential of electrons on the [4Fe-4 S] cluster of PduT, which is the proposed redox link in the BMC shell, is $+99 \mathrm{mV}$ [33] and not sufficient for sulfite reduction.

Inside the BMC, these flavins could additionally be used to shuttle electrons to IslB, which like other GRE activating enzymes might require electrons transferred by flavins to install the glycyl radical on IslA [72-74]. However, once installed, the radical is regenerated after each reaction of IslA without further electron input, meaning that IslB cannot take up the stoichiometric amounts of electrons produced by AdhE. This makes a second electron sink necessary, such as a transport out of the $\mathrm{BMC}$, for example, to pyruvate:ferredoxin oxidoreductase or DsrAB. The detailed function of apparently $\mathrm{B}_{12}$-regenerating enzymes in BMCs with $\mathrm{B}_{12}$-independent signature enzymes in combination with the unclear redox balance of the BMC, is an exciting field for further study and could provide valuable insight into the very specialized metabolism of the human gut bacterium $B$. wadsworthia. BMCs in propanediol utilization of pathogenic Salmonella enterica serovar Typhimurium have been shown to be a fitness advantage for the pathogen [75, 76], meaning that also in the opportunistic pathogen $B$. wadsworthia, a medical relevance is possible.

\section{Conclusions}

This work characterized a novel subclass of BMCs involving a carbon-sulfur bond-cleaving GRE as the signature enzyme. These microcompartments allow B. wadsworthia to efficiently utilize two organosulfonates abundant in the human gut, taurine and isethionate, as sources of sulfite as electron acceptor, and thus may reflect a structural specialization for competitive advantage, for example compared to isethionate-utilizing, but not BMCcontaining Desulfovibrio species. Aside from shedding light on the energy metabolism of the common humangut symbiont and pathogen $B$. wadsworthia, these results 
improve our knowledge of the biochemical reactions that can take place within BMCs. As BMCs are of interest for biotechnological applications such as production of chemicals or removal of contaminants from water [51, 52], this knowledge can open opportunities for an even broader application of their potential.

\section{Methods}

\section{Growth and harvest of $B$. wadsworthia}

$B$. wadsworthia 3.1.6 was grown in anoxic, carbonatebuffered, Ti(III)-reduced minimal medium as described before [1]. The medium additionally contained $200 \mu \mathrm{g} / \mathrm{l}$ naphthochinone; $20 \mathrm{mM}$ lactate and $20 \mathrm{mM}$ taurine were supplied as the electron donor and acceptor, respectively. The cells were harvested by centrifugation after $20 \mathrm{~h}$ of growth and the cell pellets stored at $-20^{\circ} \mathrm{C}$. For BMC purification, the cells were opened by three passages through a cooled French pressure cell and then centrifuged for $10 \mathrm{~min}$ at $16000 \mathrm{x}$ g to remove cell debris. Desulfovibrio alaskensis G20 was grown as a positive control for BMC formation in the same medium without naphtochinone and supplied with $40 \mathrm{mM}$ choline as sole substrate [53].

\section{Transcriptomics}

For RNA isolation, $50 \mathrm{ml}$ of overnight culture were centrifuged and the pellet was washed with $1 \mathrm{ml}$ RNAlater $^{\mathrm{TM}}$ (Invitrogen/Thermo Fisher Scientific, Waltham, MA, USA), then resuspended in $100 \mu \mathrm{RNA}$ later ${ }^{\mathrm{TM}}$ and stored at $-80{ }^{\circ} \mathrm{C}$. RNA was isolated using a Quick-RNA Miniprep kit (Zymo Research, Irvine, CA, USA) and DNA removed using a TURBO DNA-free ${ }^{\mathrm{TM}}$ kit (Invitrogen/Thermo Fisher Scientific, Waltham, MA, USA). PCR using $16 \mathrm{~S}$ forward and reverse primers was performed to confirm the absence of DNA contamination. Samples were prepared from triplicates of $B$. wadsworthia cells grown with lactate as carbon source and taurine or dihydroxypropanesulfonate as electron acceptor.

Libraries were constructed at Eurofins Genomics (Ebersberg/Konstanz, Germany) after ribosomal RNA depletion and cDNA synthesis using random hexamer primers and sequenced single-end $50 \mathrm{bp}$ on an Illumina HiSeq4000 platform.

For data analysis, the reference genome and annotation file for Bilophila wadsworthia 3_1_6 were obtained from NCBI (reference sequence: NZ_ADCP00000000.2). Raw sequence reads were quality trimmed and adapters were removed using the program Trimmomatic 0.39 [77] using the following parameters: minimum read length $30 \mathrm{bp}$, minimum average phred quality must be at least 15 in a sliding window of 4, bases at the start and end of sequences are removed if the phred quality is lower than
3. Only a small amount of reads $(<0.5 \%)$ were dropped this way (Table S1). The trimmed reads were aligned to the reference genome using the program Bowtie2 (version 2.3.5.1; [78]) with default settings and the program Samtools (version 1.9 [79]) was used to convert mapping files from "sam" to "bam" format and sort them by genomic coordinates. Stringtie (version 1.3.5 [80]) was used to assign read counts to each gene present in the provided annotation, and in combination with the PERL script prepDE.pl (http://ccb.jhu.edu/software/stringtie/) the raw count table (Table S1) was obtained as well as the transcripts per kilobase million (TPM) for each individual gene (Figure S2). For comparison to proteomic data, these values were normalized to the DsrB gene transcript count.

\section{Sucrose gradient centrifugation}

The sucrose gradient was prepared with solutions containing $10,20,30,40$, and $50 \%(\mathrm{w} / \mathrm{v})$ sucrose in $50 \mathrm{mM}$ Tris- $\mathrm{HCl}$ at $\mathrm{pH}$ 7.4. $2.5 \mathrm{ml}$ of each solution were used to form the gradient in a $14 \mathrm{ml}$ Ultra-Clear ${ }^{\mathrm{TM}}$ centrifuge tube (Beckman Coulter, Brea, CA, USA), with the highest sucrose concentration at the bottom of the tube. The cell-free extract was layered on top and the gradients were centrifuged at $85,365 \times g$ (average relative centrifugal force in a Beckman Coulter SW 40 Ti swing bucket rotor) for $16 \mathrm{~h}$ at $4{ }^{\circ} \mathrm{C}$ [81]. The resulting gradient fractions were collected in the same pattern for every individual gradient.

For proteomic analysis, the buffer was exchanged to 50 $\mathrm{mM}$ Tris- $\mathrm{HCl}$ (pH 7.9) without sucrose using $10 \mathrm{kDa}$ mass cutoff centrifugal filters (Sartorius Vivaspin 500, Sartorius AG, Göttingen, Germany), the samples were then brought to comparable protein concentrations and submitted to the Proteomics Facility of the University of Konstanz for protein mass fingerprinting. For electron microscopy, 5 $\mathrm{mM}$ Tris $-\mathrm{HCl}$ ( $\mathrm{pH}$ 7.9) without sucrose was used.

\section{SDS-PAGE and enzyme identification}

The protein content of the individual fractions was determined by Bradford assay in a total volume of $1 \mathrm{ml}$ [82]. For SDS-PAGE, gradient fractions corresponding to $50 \mu \mathrm{g}$ of protein were boiled with a loading dye $\left(\operatorname{Roti}^{\circledR}\right.$ Load 1, Carl Roth, Karlsruhe, Germany) and loaded onto a gel $(12 \%$ acrylamide in the resolving gel, $4 \%$ in the stacking gel). The gels were run at $100 \mathrm{~V}$ for $1 \mathrm{~h}$ and the proteins were visualized by Coomassie and/or silver staining (Table S3).

Individual bands were cut out of the gel and submitted for protein mass fingerprinting at the Proteomics Facility of the University of Konstanz. 


\section{Transmission electron microscopy}

Negative staining of isolated BMCs

Formvar-/Carbon-coated nickel grids (Plano $\mathrm{GmbH}$, Wetzlar, Germany) were hydrophilized by glow discharge in oxygen plasma for $45 \mathrm{~s}$, using a Harrick PDC32G2 PlasmaCleaner (Harrick Plasma, Ithaca NY, USA) at $10.2 \mathrm{~W}$ RF power. $15 \mu \mathrm{l}$ sample were applied to the grid by floating the grid on top of the sample for $2 \mathrm{~min}$. The grid was then rinsed four times with double-distilled water and contrasted with $1 \%$ phosphotungstenic acid neutralized with sodium hydroxide (5 s rinse followed by $45 \mathrm{~s}$ incubation in the contrasting solution). The grids were carefully blotted from the edge and dried thoroughly before imaging.

\section{Embedding and ultrathin sectioning of cells}

Culture samples of $B$. wadsworthia grown with taurine and lactate, of $B$. wadsworthia grown with sulfolactate and lactate and of $D$. alaskensis grown on choline were submitted to the Electron Microscopy Centre at the University of Konstanz.

The cells were enclosed in agarose and fixed with $2.5 \%$ glutardialdehyde in $0.05 \mathrm{M}$ HEPES buffer at $\mathrm{pH} 7$ for $2.5 \mathrm{~h}$. After initial dehydration in a graded ethanol series, postfixation was performed with $2 \% \mathrm{OsO}_{4}$ for one hour at $0{ }^{\circ} \mathrm{C}$, and samples were stained en-bloc with a saturated solution of uranyl acetate in $70 \%$ ethanol. Following further dehydration in a graded acetone series the agarose blocs were embedded in Spurr's resin (Spurr's Low Viscosity embedding kit, Sigma Aldrich, St Louis, USA) using acetone as intermedium, and polymerized at $65{ }^{\circ} \mathrm{C}$ for $48 \mathrm{~h}$. A detailed description of the process can be found in Table S4.

Ultramicrotomy was performed on a Leica UC7 ultramicrotome (Leica Microsystems, Wetzlar, Germany) using a diamond knife (Diatome $45^{\circ}$ Ultra, diatome, Nidau, Switzerland). Ultrathin sections (50nm) were mounted on formvar-coated copper mesh grids, incubated on a drop of saturated aequous uranylacetate solution $(\sim 7.8 \%)$ for $20 \mathrm{~min}$ in the dark, then rinsed with double distilled water for $10 \mathrm{~s}$ and dried. They were then incubated for $90 \mathrm{~s}$ on a drop of $0.4 \%$ lead citrate and $0.4 \%$ sodium hydroxide solution under carbon dioxide-free conditions, rinsed for $10 \mathrm{~s}$ with double distilled water and dried overnight under air according to [83].

\section{Transmission electron microscopy imaging}

Samples were analyzed using a Zeiss EM 912 Omega (Zeiss, Oberkochen, Germany) transmission electron microscope equipped with a thermionic tungsten cathode, and a TRS slow scan CCD-camera for TEM (Tröndle Restlichtverstärker Systeme, Moorenweis, Germany). The images were taken at an acceleration voltage of $80 \mathrm{kV}$ and processed using ImageSP ver.1.2.3.36 (SYS-PROG, Minsk, Belarus \& Tröndle Restlichtverstärker Systeme, Moorenweis, Germany).

\section{Enzyme assays Taurine-pyruvate aminotransferase (Tpa)}

Taurine-pyruvate aminotransferase activity was measured aerobically as taurine consumption and alanine formation in a solution of $5 \mathrm{mM}$ taurine and $5 \mathrm{mM}$ pyruvate in $50 \mathrm{mM}$ Tris $-\mathrm{HCl}$ at $\mathrm{pH}$ 7.9. The cofactor pyridoxal5-phosphate was additionally supplied in a concentration of $0.1 \mathrm{mM}$ in all buffers used in the assay or during purification. Typically, $0.2 \mathrm{ml}$ of cell-free extract or gradient fraction were used for an assay on a $1 \mathrm{ml}$ scale. Taurine and alanine concentrations were measured by HPLC as described in [1]. Each fraction was assayed in triplicates.

\section{Sulfoacetaldehyde reductase (SarD)}

SarD activity was measured under oxic conditions in 50 $\mathrm{mM}$ Tris $-\mathrm{HCl}$ buffer at $\mathrm{pH} 7.9$ with $0.4 \mathrm{mM}$ sulfoacetaldehyde and $0.2 \mathrm{mM} \mathrm{NADH}$ provided as substrates. The decrease of NADH concentration was measured at $340 \mathrm{~nm}$ in a spectrophotometer (JASCO, Tokyo, Japan). $100 \mu \mathrm{l}$ of gradient fraction were used in one assay and the background activity of the protein solution with NADH only was measured separately before adding sulfoacetaldehyde. Each fraction was assayed in triplicates.

\section{Isethionate sulfite lyase (IsIAB)}

For measuring isethionate sulfite lyase activity, the gradient was prepared from anoxic sucrose solutions under a $95 \% \mathrm{~N}_{2} / 5 \% \mathrm{H}_{2}$ atmosphere and centrifuged in sealed tubes as described above. The fractions were separated in a $95 \% \mathrm{~N}_{2} / 5 \% \mathrm{H}_{2}$ atmosphere. The enzyme assays were carried out in anoxic $50 \mathrm{mM}$ Tris- $\mathrm{HCl}$ buffer at $\mathrm{pH}$ 7.9. The reaction mixture contained $20 \mathrm{mM}$ isethionate, 1 $\mathrm{mM}$ SAM hydrochloride, $2 \mathrm{mg} / \mathrm{l}$ resazurin as a redox indicator and $1 \mathrm{mM} \mathrm{Ti}(\mathrm{III})-\mathrm{NTA}$ as a reducing agent. The reactions were carried out in anoxic stoppered $1 \mathrm{ml}$ glass cuvettes with a $95 \% \mathrm{~N}_{2} / 5 \% \mathrm{H}_{2}$ gas phase. The reaction was started by addition of $200 \mu \mathrm{l} / \mathrm{ml}$ gradient fraction solution. Samples were taken at one hour intervals using analytical syringes. Each fraction was assayed in triplicates.

For acetaldehyde quantification, $50 \mu \mathrm{l}$ of the reaction were added to a $2.5 \mathrm{mM}$ solution of 2,4-dinitrophenylhydrazine $(\mathrm{DNPH})$ in acetonitrile with $0.1 \%$ phosphoric acid. The derivatization reaction was incubated for at least $30 \mathrm{~min}$ at room temperature (modified after [84]).

For sulfite quantification, $50 \mu \mathrm{l}$ of the reaction were added to $0.25 \mathrm{M}$ borate buffer with $0.25 \mathrm{M} \mathrm{KCl}$ and 20 mM EDTA, adjusted to $\mathrm{pH} 10$ with sodium carbonate. $50 \mu \mathrm{l}$ of a $10 \mathrm{mM}$ solution of $N$-(9-acridinyl)-maleimide 
(NAM) in acetone were added and the reaction was incubated for $30 \mathrm{~min}$ at $50{ }^{\circ} \mathrm{C}$ [85].

All derivatized samples were frozen once to precipitate proteins and then centrifuged for $30 \mathrm{~s}$. Derivatized sulfite respectively acetaldehyde were analyzed by HPLC on a

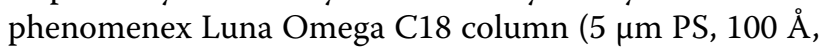
$150 \times 3 \mathrm{~mm}$, phenomenex/Danaher; Washington D.C., USA) with acetonitrile and $0.1 \%$ formic acid in water as mobile phases. The Shimadzu Prominence HPLC (Shimadzu, Kyoto, Japan) was equipped with a SPD-M20A photodiode array detector and the detection wavelengths were $254 \mathrm{~nm}$ for NAM-sulfite adducts and $360 \mathrm{~nm}$ for DNPH derivatives. The HPLC gradient programmes were as follows: For DNPH derivates: $25 \%$ acetonitrile for $4.5 \mathrm{~min}$, followed by a rise to $70 \%$ acetonitrile over $15 \mathrm{~min}$ and $10 \mathrm{~min}$ reequilibration to $25 \%$ acetonitrile. For NAM-sulfite: $3 \mathrm{~min}$ at $10 \%$ acetonitrile, gradient to $80 \%$ acetonitrile during $10 \mathrm{~min}$, reequilibration to $10 \%$ acetonitrile for $7 \mathrm{~min}$.

\section{Acetylating acetaldehyde dehydrogenase (AdhE)}

To determine acetaldehyde dehydrogenase activity, the reduction of $\mathrm{NAD}^{+}$to NADH was measured photometrically (modified after [86]) under oxic conditions. One assay typically contained $0.25 \mathrm{mM} \mathrm{NAD}^{+}, 5-25 \mu \mathrm{l}$ gradient fraction, $2 \mathrm{mM}$ acetaldehyde and $0.33 \mathrm{mM}$ coenzyme A in a total volume of $1 \mathrm{ml}$ anoxic $50 \mathrm{mM}$ potassium phosphate buffer with $3 \mathrm{mM}$ dithiothreitol (DTT) at a $\mathrm{pH}$ of 7.5. The formation of NADH was monitored for one minute at $340 \mathrm{~nm}$. To be able to calculate the activity of acetylating acetaldehyde dehydrogenase specifically, each fraction was measured in one assay with coenzyme A, yielding total acetaldehyde dehydrogenase activity, and one without coenzyme A to measure non-acetylating acetaldehyde dehydrogenase activity. The activity of acetylating acetaldehyde dehydrogenase was calculated as the difference between these two measurements. Each fraction was assayed in triplicates.

\section{Phosphotransacetylase (Pta)}

Phosphotransacetylase activity was measured as the backwards reaction from acetyl phosphate to acetyl-CoA, with the acetyl-CoA formation being measured photometrically ( [87] modified after [88]). $3.33 \mathrm{mM}$ acetyl phosphate and $0.33 \mathrm{mM}$ coenzyme A were incubated i $50 \mathrm{mM}$ Tris $-\mathrm{HCl}$ buffer at a $\mathrm{pH}$ of 7.5. 10 to100 $\mu \mathrm{l}$ of gradient fraction per $\mathrm{ml}$ were added and the formation of acetyl-CoA was monitored for one minute at $233 \mathrm{~nm}$. Each fraction was measured in triplicates.

\section{Acetate kinase (AckA)}

The activity of acetate kinase was measured as the consumption of acetyl phosphate, which was quantified using a colorimetric assay based on the formation of acyl-hydroxamate chelation with $\mathrm{Fe}^{3+}$ ( [87] modified after [89]). The enzymatic reaction was set up in a volume of $1 \mathrm{ml}$ containing $5 \mathrm{mM}$ ADP, $5 \mathrm{mM} \mathrm{MgCl}_{2}, 3.33$ $\mathrm{mM}$ acetyl phosphate and 5 to $25 \mu \mathrm{l}$ gradient fraction in $50 \mathrm{mM}$ Tris - $\mathrm{HCl}$ buffer at a $\mathrm{pH}$ of 7.4. The reactions were incubated shaking at room temperature $\left(23{ }^{\circ} \mathrm{C}\right)$ and samples of $300 \mu \mathrm{l}$ for the determination of acetyl phosphate concentration were taken at time intervals of 2 or 5 min depending on the reaction speed.

The samples were added to $200 \mu \mathrm{l}$ of a $2.5 \mathrm{M}$ solution of hydroxylamine hydrochloride in water, freshly neutralized with $\mathrm{NaOH}$. This mixture was stored on ice until the complete batch could be incubated at room temperature for ten minutes. $0.5 \mathrm{ml}$ of the $\mathrm{Fe}(\mathrm{III})$ reagent were then added: $3 \%(\mathrm{w} / \mathrm{v}) \mathrm{FeCl}_{3}$ dissolved in $0.1 \mathrm{M} \mathrm{HCl}, 12 \%(\mathrm{w} / \mathrm{v})$ trichloroacetic acid in water, and $3 \mathrm{M} \mathrm{HCl}$ were mixed in equal amounts to obtain this reagent. The reaction was mixed thoroughly and the absorption of the $\mathrm{Fe}(\mathrm{III})$ chelates was measured at $540 \mathrm{~nm}$. The absorption values were quantified using a freshly prepared acetyl phosphate standard. Each fraction was measured in triplicates.

\section{Statistical evaluation}

Statistical evaluations of enzyme activities in the gradient fractions were performed in Origin 8. Based on the assumption of dependent samples, one-way repeated measures ANOVA was performed with an overall significance level of 0.05 and a Tukey test employed for pairwise means comparison.

\section{Protein alignment}

Genome search was performed and annotations were taken from JGI IMG/M on 28.6.2019. HMPREF0179_00647 was identified as PduT by Basic Local Alignment Search Tool on UniProt. The search was conducted using the amino acid sequence of HMPREF0179_00647 against UniProt reference proteomes plus Swiss-Prot, with an E-threshold of 10 and no filtering and gapping allowed. For alignments with PduT of Citrobacter freundii and Salmonella typhimurium, the respective proteins sequences were taken from the UniProt database and aligned with the amino acid sequence of HMPREF0179_00647 using default settings.

\section{Supplementary Information}

The online version contains supplementary material available at https://doi. org/10.1186/s12866-021-02386-w.

Additional file 1. 


\section{Acknowledgements}

We thank Karin Denger for help with cultivation and Alexander Fiedler, Alina Kindinger and Anne Van Humbeeck for experimental support in Hiwiprojects or during practical classes. We are grateful to Andreas Marquardt for proteomics.

\section{Authors' contributions}

$A G B$ and $D S$ designed the experiments. AGB, SD, PB and SH performed the experiments and analyzed the data. $A G B, P F$ and $C F$ did the transcriptomic analyses. El and AK provided support with method development. AGB and DS wrote the manuscript and all authors approved it.

\section{Funding}

Open Access funding enabled and organized by Projekt DEAL. This work was funded by the Deutsche Forschungsgemeinschaft (DFG) (to DS; grant SCHL 1936/4) and the University of Konstanz and Konstanz Research School Chemical Biology (KoRS-CB) (to AGB)

\section{Availability of data and materials}

The Bilophila wadsworthia 3.1.6 transcriptome sequencing datasets generated and analysed during the current study are available in NCBI's BioProject repository, under ID\# PRJNA769660 (https://www.ncbi.n/m.nih.gov/bioproject/ 769660)

\section{Declarations}

\section{Ethics approval and consent to participate}

Not applicable.

\section{Consent for publication}

Not applicable.

\section{Competing interests}

The authors declare no competing interest.

\section{Author details}

${ }^{1}$ Department of Biology, University of Konstanz, Konstanz, Germany. ${ }^{2}$ Konstanz Research School Chemical Biology, University of Konstanz, Konstanz, Germany. ${ }^{3}$ Present Address: Max von Pettenkofer Institute of Hygiene and Medical Microbiology, Faculty of Medicine, LMU Munich, Munich, Germany. ${ }^{4}$ Electron Microscopy Centre, Department of Biology, University of Konstanz, Konstanz, Germany.

Received: 8 July 2021 Accepted: 8 November 2021

Published online: 13 December 2021

\section{References}

1. Peck SC, Denger K, Burrichter A, Irwin SM, Balskus EP, Schleheck D. A glycyl radical enzyme enables hydrogen sulfide production by the human intestinal bacterium Bilophila wadsworthia. Proc Natl Acad Sci USA. 2019;116:3171.

2. Laue $H$, Denger $K$, Cook AM. Taurine reduction in anaerobic respiration of Bilophila wadsworthia RZATAU. Appl Environ Microbiol. 1997;63:2016-21.

3. Levine J, Ellis CJ, Furne JK, Springfield J, Levitt MD. Fecal hydrogen sulfide production in ulcerative colitis. Am J Gastroenterol. 1998:93:83-7.

4. Roediger WE, Moore J, Babidge W. Colonic sulfide in pathogenesis and treatment of ulcerative colitis. Digestive Dis Sci. 1997;42:1571-9.

5. Wallace JL. Physiological and pathophysiological roles of hydrogen sulfide in the gastrointestinal tract. Antioxidants Redox Signaling. 2010;12:1125-33.

6. Carbonero F, Benefiel AC, Alizadeh-Ghamsari AH, Gaskins HR. Microbial pathways in colonic sulfur metabolism and links with health and disease. Front Physiol. 2012;3:448.

7. Ijssennagger N, Belzer C, Hooiveld GJ, Dekker J, van Mil SW, Muller M, Kleerebezem M, van der Meer R. Gut microbiota facilitates dietary hemeinduced epithelial hyperproliferation by opening the mucus barrier in colon. Proc Natl Acad Sci USA. 2015;112:10038-43.
8. Ijssennagger N, van der Meer R, van Mil SWC. Sulfide as a mucus barrierbreaker in inflammatory bowel disease? Trends Mol Med. 2016:22:190-9.

9. Attene-Ramos MS, Wagner ED, Gaskins HR, Plewa MJ. Hydrogen sulfide induces direct radical-associated DNA damage. Mol Cancer Res. 2007;5:455-9.

10. Attene-Ramos MS, Wagner ED, Plewa MJ, Gaskins HR. Evidence that hydrogen sulfide is a genotoxic agent. Mol Cancer Res. 2006;4:9.

11. Hanson BT, Dimitri Kits K, Löffler J, Burrichter AG, Fiedler A, Denger K, Frommeyer B, Herbold CW, Rattei T, Karcher N, Segata N, Schleheck D, Loy A. Sulfoquinovose is a select nutrient of prominent bacteria and a source of hydrogen sulfide in the human gut. ISME J. 2021. https://doi.org/10. 1038/s41396-021-00968-0.

12. Olson KR, Straub KD. 2016. The Role of Hydrogen Sulfide in Evolution and the Evolution of Hydrogen Sulfide in Metabolism and Signaling. Physiology (Bethesda) 31:60-72.

13. Banerjee R. 2011. Hydrogen sulfide: redox metabolism and signaling. Antioxid Redox Signal 15:339-41.

14. Huxtable RJ. Physiological actions of taurine. Physiol Reviews. 1992;72:101-63.

15. Ripps H, Shen W. 2012. Review: Taurine: A "very essential" amino acid. Molecular Vision 18:2673-2686.

16. Farag AS, Klikarova J, Ceslova L, Vytras K, Sys M. 2019. Voltammetric determination of taurine in energy drinks after o-phthalaldehyde-ethanethiol derivatization. Talanta 202:486-493.

17. Holst PB, Nielsen SE, Anthoni U, Bisht KS, Christophersen C, Gupta S, Parmar VS, Nielsen PH, Sahoo DB, Singh A. Isethionate in certain red algae. J Appl Phycol. 1994;6:443-6.

18. Koechlin BA. The isolation and identification of the major anion fraction of the axoplasm of squid qiant nerve fibers. Proc Natl Acad Sci USA. 1954;40:60-2.

19. Spaeth DG, Schneider DL. Taurine synthesis, concentration, and bile salt conjugation in rat, guinea pig, and rabbit. Proc Soc Experiment Biol Med. 1974; 147:855-8.

20. Brand HS, Jorning GG, Chamuleau RA. 1998. Changes in urinary taurine and hypotaurine excretion after two-thirds hepatectomy in the rat. Amino Acids 15:373-83.

21. Ridlon JM, Wolf PG, Gaskins HR. 2016. Taurocholic acid metabolism by gut microbes and colon cancer. Gut Microbes 7:201-215.

22. Devkota S, Wang Y, Musch MW, Leone V, Fehlner-Peach H, Nadimpalli A, Antonopoulos DA, Jabri B, Chang EB. 2012. Dietary-fat-induced taurocholic acid promotes pathobiont expansion and colitis in /110-/- mice. Nature 487:104-108

23. Xing $M$, Wei $Y$, Zhou Y, Zhang J, Lin L, Hu Y, Hua G, Nanjaraj Urs N, Liu A, Wang D, Guo F, Tong C, Li Y, Liu M, Ang Y, Zhao EL, Yuchi H, Zhang Z. Radical-mediated C-S bond cleavage in $\mathrm{C}_{2}$-sulfonate degradation by anaerobic bacteria. Nature Commun. 2019;10:1609.

24. Kappler U, Enemark JH. Sulfite-oxidizing enzymes. JBIC J Biol Inorganic Chem. 2015;20:253-64.

25. Tan YJC, Zhao C, Nasreen M, O'Rourke L, Dhouib R, Roberts L, Wan Y, Beatson SA, Kappler U. Control of bacterial sulfite detoxification by conserved and species-specific regulatory circuits. Front Microbiol. 2019;10.

26. Laue H, Cook AM. Biochemical and molecular characterization of taurine:pyruvate aminotransferase from the anaerobe Bilophila wadsworthia. Eur J Biochem. 2000;267:6841-8.

27. Laue $H_{1}$ Cook AM. Purification, properties and primary structure of alanine dehydrogenase involved in taurine metabolism in the anaerobe Bilophila wadsworthia. Arch Microbiol. 2000;174:162-7.

28. Kofoid E, Rappleye C, Stojiljkovic I, Roth J. The 17-gene ethanolamine (eut) operon of Salmonella typhimurium encodes five homologues of carboxysome shell proteins. J Bacteriol. 1999;181:5317-29.

29. Tanaka S, Kerfeld CA, Sawaya MR, Cai F, Heinhorst S, Cannon GC, Yeates TO. 2008. Atomic-level models of the bacterial carboxysome shell. Science 319:1083

30. Moore TC, Escalante-Semerena JC. The EutQ and EutP proteins are novel acetate kinases involved in ethanolamine catabolism: physiological implications for the function of the ethanolamine metabolosome in Salmonella enterica. Mol Microbiol. 2016;99:497-511.

31. Crowley CS, Cascio D, Sawaya MR, Kopstein JS, Bobik TA, Yeates TO. Structural insight into the mechanisms of transport across the Salmonella enterica Pdu microcompartment shell. J Biol Chem. 2010;285:37838-46. 
32. Pang A, Warren MJ, Pickersgill RW. 2011. Structure of PduT, a trimeric bacterial microcompartment protein with a $4 \mathrm{Fe}-4 \mathrm{~S}$ cluster-binding site. Acta Crystallographica Section D Biological Crystallography 67:91-6.

33. Parsons JB, Dinesh SD, Deery E, Leech HK, Brindley AA, Heldt D, Frank S, Smales CM, Lunsdorf H, Rambach A, Gass MH, Bleloch A, McClean KJ, Munro AW, Rigby SE, Warren MJ, Prentice MB. Biochemical and structural insights into bacterial organelle form and biogenesis. J Biol Chem. 2008;283:14366-75.

34. da Silva SM, Venceslau S, Fernandes CLV, Valente F, Cardoso Pereira I. 2008. Hydrogen as an energy source for the human pathogen Bilophila wadsworthia. Antonie Van Leeuwenhoek 93:381-90.

35. Kerfeld CA, Aussignargues C, Zarzycki J, Cai F, Sutter M. Bacterial microcompartments. Nature Reviews Microbiol. 2018;16:277-90.

36. Erbilgin $\mathrm{O}, \mathrm{McDonald} \mathrm{KL}$, Kerfeld CA. Characterization of a planctomycetal organelle: a novel bacterial microcompartment for the aerobic degradation of plant saccharides. Appl Environ Microbiol. 2014;80:2193-205.

37. Liberton M, Austin JR, Berg RH, Pakrasi HB. Unique thylakoid membrane architecture of a unicellular $\mathrm{N}_{2}$-fixing cyanobacterium revealed by electron tomography. Plant Physiol. 2011;155:1656.

38. Cannon GC, Bradburne CE, Aldrich HC, Baker SH, Heinhorst S, Shively JM. Microcompartments in prokaryotes: carboxysomes and related polyhedra. Appl Environ Microbiol. 2001;67:5351-61.

39. Codd GA, Marsden WJN. 1984. The carboxysomes (polyhedral bodies) of autotrophic prokaryotes. Biological Reviews 59:389-422.

40. Tabita FR. 1999. Microbial ribulose 1,5-bisphosphate carboxylase/oxygenase: A different perspective. Photosynthesis Research 60:1-28.

41. Shively JM, Ball F, Brown DH, Saunders RE. 1973. Functional organelles in prokaryotes: polyhedral inclusions (carboxysomes) of Thiobacillus neapolitanus. Science 182:584-6.

42. Brinsmade SR, Paldon T, Escalante-Semerena JC. Minimal functions and physiological conditions required for growth of Salmonella enterica on ethanolamine in the absence of the metabolosome. J Bacteriol. 2005;187:8039-46.

43. Stojiljkovic I, Bäumler AJ, Heffron F. Ethanolamine utilization in Salmonella typhimurium: nucleotide sequence, protein expression, and mutational analysis of the cchA cchB eutE eutJ eutG eutH gene cluster. J Bacteriol. 1995; 177:1357.

44. BobikTA, Havemann GD, Busch RJ, Williams DS, Aldrich HC. The propanediol utilization ( $p d u$ ) operon of Salmonella enterica serovar Typhimurium LT2 includes genes necessary for formation of polyhedral organelles involved in coenzyme $B_{12}$-dependent 1,2-propanediol degradation. J Bacteriol. 1999;181:5967-75.

45. Kerfeld CA, Heinhorst S, Cannon GC. Bacterial microcompartments. Ann Review Microbiol. 2010;64:391-408.

46. Chowdhury C, Sinha S, Chun S, Yeates TO, Bobik TA. Diverse bacterial microcompartment organelles. Microbiol Mol Biol Reviews. 2014;78:438-68.

47. Bonacci W, Teng PK, Afonso B, Niederholtmeyer H, Grob P, Silver PA, Savage DF. 2012. Modularity of a carbon-fixing protein organelle. Proc Natl Acad Sci U S A 109:478-83.

48. Baumgart M, Huber I, Abdollahzadeh I, Gensch T, Frunzke J. 2017. Heterologous expression of the Halothiobacillus neapolitanus carboxysomal gene cluster in Corynebacterium glutamicum. J Biotechnol 258:126-135.

49. Lin MT, Occhialini A, Andralojc PJ, Devonshire J, Hines KM, Parry MA, Hanson MR. 2014. $\beta$-Carboxysomal proteins assemble into highly organized structures in Nicotiana chloroplasts. Plant J 79:1-12.

50. Lin MT, Occhialini A, Andralojc PJ, Parry MA, Hanson MR. 2014. A faster Rubisco with potential to increase photosynthesis in crops. Nature 513:547-50.

51. Lawrence AD, Frank S, Newnham S, Lee MJ, Brown IR, Xue WF, Rowe ML, Mulvihill DP, Prentice MB, Howard MJ, Warren MJ. 2014. Solution structure of a bacterial microcompartment targeting peptide and its application in the construction of an ethanol bioreactor. ACS Synthetic Biology 3:454-465.

52. Liang M, Frank S, Lünsdorf H, Warren MJ, Prentice MB. Bacterial microcompartment-directed polyphosphate kinase promotes stable polyphosphate accumulation in E. coli. Biotechnol J. 2017;12:1600415.

53. Craciun S, Balskus EP. Microbial conversion of choline to trimethylamine requires a glycyl radical enzyme. Proc Natl Acad Sci USA. 2012;109:21307-12
54. Herring TI, Harris TN, Chowdhury C, Mohanty SK, Bobik TA. A bacterial microcompartment is used for choline fermentation by Escherichia coli 536. J Bacteriol. 2018;200:e00764-17.

55. Petit E, LaToufWG, Coppi MV, WarnickTA, Currie D, Romashko I, Deshpande S, Haas K, Alvelo-Maurosa JG, Wardman C, Schnell DJ, Leschine SB, Blanchard JL. 2013. Involvement of a bacterial microcompartment in the metabolism of fucose and rhamnose by Clostridium phytofermentans. PloS ONE 8:e54337-e54337.

56. O'Brien JR, Raynaud C, Croux C, Girbal L, Soucaille P, Lanzilotta WN. 2004 Insight into the mechanism of the $B_{12}$-independent glycerol dehydratase from Clostridium butyricum: preliminary biochemical and structural characterization. Biochemistry 43:4635-45

57. Raynaud C, Sarçabal P, Meynial-Salles I, Croux C, Soucaille P. Molecular characterization of the 1,3-propanediol (1,3-PD) operon of Clostridium butyricum. Proc Natl Acad Sci USA. 2003;100:5010-5.

58. Schindel HS, Karty JA, McKinlay JB, Bauer CE. Characterization of a glycylradical enzyme bacterial microcompartment pathway in Rhodobacter capsulatus. J Bacteriol. 2018. https://doi.org/10.1128/JB.00343-18:JB. 00343-18.

59. Zarzycki J, Erbilgin O, Kerfeld CA. Bioinformatic characterization of glycyl radical enzyme-associated bacterial microcompartments. Appl Environ Microbiol. 2015:81:8315-29.

60. Axen SD, Erbilgin O, Kerfeld CA. A taxonomy of bacterial microcompartment loci constructed by a novel scoring method. PLoS Computational Biol. 2014;10:e1003898.

61. Craciun S, Marks JA, Balskus EP. Characterization of choline trimethylamine-lyase expands the chemistry of glycyl radical enzymes. ACS Chem Biol. 2014;9:1408-13.

62. Rein U, Gueta R, Denger K, Ruff J, Hollemeyer K, Cook AM. 2005. Dissimilation of cysteate via 3-sulfolactate sulfo-lyase and a sulfate exporter in Paracoccus pantotrophus NKNCYSA. Microbiology 151:737-47.

63. Burrichter A, Denger K, Franchini P, Huhn T, Müller N, Spiteller D, Schleheck D. Anaerobic degradation of the plant sugar sulfoquinovose concomitant with $\mathrm{H}_{2} \mathrm{~S}$ production: Escherichia coli $\mathrm{K}-12$ and Desulfovibrio sp. strain DF1 as co-culture model. Front Microbiol. 2018; 9.

64. Kuehl JV, Price MN, Ray J, Wetmore KM, Esquivel Z, Kazakov AE, Nguyen M, Kuehn R, Davis RW, Hazen TC, Arkin AP, Deutschbauer A. 2014. Functional genomics with a comprehensive library of transposon mutants for the sulfate-reducing bacterium Desulfovibrio alaskensis G20. mBio 5:e01041-14.

65. Liu J, Wei Y, Lin L, Teng L, Yin J, Lu Q, Chen J, Zheng Y, Li Y, Xu R, Zhai W Liu Y, Liu Y, Cao P, Ang EL, Zhao H, Yuchi Z, Zhang Y. 2020. Two radicaldependent mechanisms for anaerobic degradation of the globally abundant organosulfur compound dihydroxypropanesulfonate. Proc Nat Acad Sci U S A 117:15599-15608.

66. Huseby DL, Roth JR. 2013. Evidence that a metabolic microcompartment contains and recycles private cofactor pools. Journal of Bacteriology 195:2864.

67. Cheng S, Fan C, Sinha S, Bobik TA. 2012. The PduQ enzyme is an alcohol dehydrogenase used to recycle $\mathrm{NAD}^{+}$internally within the Pdu microcompartment of Salmonella enterica. PloS ONE 7:e47144.

68. Ferlez B, Sutter M, Kerfeld CA. Glycyl radical enzyme-associated microcompartments: Redox-replete bacterial organelles. Mol Biol Physiol. 2019;10:e02327-18.

69. Cheng S, Bobik TA. Characterization of the PduS cobalamin reductase of Salmonella enterica and its role in the Pdu microcompartment. J Bacteriol. 2010;192:5071-80.

70. Parsons JB, Lawrence AD, McLean KJ, Munro AW, Rigby SEJ, Warren MJ. 2010. Characterisation of PduS, the pdu metabolosome corrin reductase, and evidence of substructural organisation within the bacterial microcompartment. PloS ONE 5:e14009-e14009.

71. Zeng Z, Boeren S, Bhandula V, Light SH, Smid EJ, Notebaart RA, Abee T, Laar TAV. 2021. Bacterial Microcompartments Coupled with Extracellular Electron Transfer Drive the Anaerobic Utilization of Ethanolamine in Listeria monocytogenes. mSystems 6:e01349-20.

72. Bianchi V, Eliasson R, Fontecave M, Mulliez E, Hoover DM, Matthews RG, Reichard P. Flavodoxin is required for the activation of the anaerobic ribonucleotide reductase. Biochem Biophysica Res Commun. 1993;197:792-7.

73. Backman LRF, Funk MA, Dawson CD, Drennan CL. 2017. New tricks for the glycyl radical enzyme family. Critical Reviews in Biochemistry and Molecular Biology 52:674-695. 
74. Shisler KA, Broderick JB. 2014. Glycyl radical activating enzymes: Structure, mechanism, and substrate interactions. Archives of Biochemistry and Biophysics 546:64-71.

75. Klumpp J, Fuchs TM. 2007. Identification of novel genes in genomic islands that contribute to Salmonella typhimurium replication in mac rophages. Microbiology (Reading) 153:1207-1220.

76. Harvey PC, Watson M, Hulme S, Jones MA, Lovell M, Berchieri A, Jr., Young J, Bumstead N, Barrow P. 2011. Salmonella enterica serovar typhimurium colonizing the lumen of the chicken intestine grows slowly and upregulates a unique set of virulence and metabolism genes. Infect Immun 79:4105-21.

77. Bolger AM, Lohse M, Usadel B. 2014. Trimmomatic: a flexible trimmer for Illumina sequence data. Bioinformatics 30:2114-2120.

78. Langmead B, Salzberg SL. 2012. Fast gapped-read alignment with Bowtie 2. Nature Methods 9:357-359.

79. Li H, Handsaker B, Wysoker A, Fennell T, Ruan J, Homer N, Marth G, Abecasis G, Durbin R. 2009. The Sequence Alignment/Map format and SAMtools. Bioinformatics 25:2078-9.

80. Pertea M, Pertea GM, Antonescu CM, Chang T-C, Mendell JT, Salzberg SL. StringTie enables improved reconstruction of a transcriptome from RNAseq reads. Nature Biotechnol. 2015;33:290.

81. Huber I. 2017. Establishment of bacterial microcompartments in the industrial production strain Corynebacterium glutamicumHeinrich-HeineUniversität Düsseldorf; Forschungszentrum Jülich, Jülich.

82. Bradford MM. A rapid and sensitive method for the quantitation of microgram quantities of protein utilizing the principle of protein-dye binding. Analytical Biochem. 1976;72:248-54.

83. Venable $\mathrm{JH}$, Coggeshall R. A simplified lead citrate stain for use in electron microscopy. J Cell Biol. 1965;25:407.

84. Frey J, Schneider F, Schink B, Huhn T. Synthesis of short-chain hydroxyaldehydes and their 2,4-dinitrophenylhydrazone derivatives, and separation of their isomers by high-performance liquid chromatography. J Chromatography A. 2018;1531:143-50.

85. Akasaka K, Matsuda H, Ohrui H, Meguro H, Suzuki T. Fluorometric determination of sulfite in wine by $\mathrm{N}$-(9-acridinyl)maleimide. Agricultural Biol Chem. 1990;54:501-4.

86. Hensgens CM, Hagen WR, Hansen TA. Purification and characterization of a benzylviologen-linked, tungsten-containing aldehyde oxidoreductase from Desulfovibrio gigas. J Bacteriol. 1995;177:6195-200.

87. Müller N, Griffin BM, Stingl U, Schink B. Dominant sugar utilizers in sediment of Lake Constance depend on syntrophic cooperation with methanogenic partner organisms. Environ Microbiol. 2008:10:1501-11.

88. Bergmeyer HU. 1970. Methoden der enzymatischen Analyse. Bd 2. Vlg. Chemie.

89. Nishimura JS, Griffith MJ. Acetate kinase from Veillonella alcalescens: EC 2.7.2.1 ATP:acetate phosphotransferase. Methods Enzymol. 1981;71:11-316. Academic Press.

\section{Publisher's Note}

Springer Nature remains neutral with regard to jurisdictional claims in published maps and institutional affiliations.

Ready to submit your research? Choose BMC and benefit from:

- fast, convenient online submission

- thorough peer review by experienced researchers in your field

- rapid publication on acceptance

- support for research data, including large and complex data types

- gold Open Access which fosters wider collaboration and increased citations

- maximum visibility for your research: over $100 \mathrm{M}$ website views per year

At BMC, research is always in progress.

Learn more biomedcentral.com/submissions 